\title{
CAPACITY BUILDING FOR WOMEN IN AFRICAN COUNTRIES A Case Study of Sierra Leone
}

\author{
MASERAY NGADIE ROGERS \\ Centre for Contemporary International Relations Studies \\ Jilin University, \\ Youyi Hui Guan, Changchun, China \\ Email:mnbangura@gmail.com
}

\begin{abstract}
Capacity-building has become an attractive and important component of development planning and programming in Sierra Leone's post-conflict rebuilding. The breakdown of socio-economic structures and infrastructure under conflict has warranted ongoing efforts to restore peace and promote development. Consequently, qualitative and quantitative measures at facilitating the process have become key in the capacity-building process. In the case of the women of Sierra Leone, this has further inured from histories of discrimination most of which stem from sociocultural factors and forces. Ongoing efforts have thus targeted women's capacity-building as part of efforts to empower them. This work examines capacity building efforts for the women of Sierra Leone. It focuses on how global and national efforts have served women's empowerment needs socio-economically and politically. It argues that socio-cultural factors have been critical in limiting benefits from the efforts. The paper is informed by conceptual analysis of existing literature and official documentation. It finds a trend of movement building, which has been championed by NGOs, whose efforts have been supported by global movements and yet impeded by the gendered socio-cultural contexts in which the NGOs operate and within which programming interventions have been implemented.
\end{abstract}

KEY WORDS: Women's Empowerment, Social Movements, Non-government organizations, gendered socio-cultural system, capacity-building.

\section{INTRODUCTION}

The motivation for building women's capacities lies in the clear manifestation of the gendered meanings, systems and structures that define and shape the socio-economic system of Sierra Leone. Scholarly research and popular media agree that the women of Sierra Leone have and continue to suffer various forms of injustices. The long history of gender based discrimination can be traced to cultural meanings, colonial compromises and the general lack of concerted effort to change the situation. Obvious forms of violence and abuse of women such as wifebeating, rape and servitude which are frequently reported in the local media as clear evidence of gender based discrimination have hardly addressed and often go unpunished. Yet in recent time with the rise in social movements, globally and locally, women's human rights abuses and gender based discrimination have attained a higher pedestal in development efforts. Nationally, non-governmental organizations and the state through its institutions are taking women's and gender equality issues more seriously (Dutton, 1995). 
The UN, through its structures and systems has played a leading role in championing the cause of women globally. Through the institution of women's day celebrations and decade of women and special structures such as the Committee on Status of Women and UNIFEM as well as facilitation of fora such as Women's International Conferences (Nairobi 1985 and Beijing 1995) have created opportunities for global discussion, women's movement and strategizing for national responses in the form of the creation of national machineries and gender and women's policies (Bunch, 1997; Tsikata, 1998; DAWN, 1986).

In spite of ongoing efforts, the status of women remains low. The deep and wide socio-economic gaps in the form educational enrolments and attainments, access to health services and reproductive health care, participation in politics, public life and decision-making, feminization of poverty due to low incomes and poor access to paid employment all lead to the poor conditions and low status of women (Tsikata \& Kerr, 2000; Ogundipe-Leslie, 1994).

The latest available data on Africa show that 80 million girls of primary school age (6 to 11) are not in school as compared to 52 million boys. This was indicated in the Millennium Development Goals' Report (Annan, 2005). Moreover, even those gross enrolment rates are often marred with high levels of absenteeism and dropout rates due to competing demands such as marriage, household chores and reproductive responsibilities, among others. The data show that dropout rates are notably high in low-income countries, but vary by gender worldwide, and within regions. Drop-out rates for girls tend to be related to age, peaking at about grade 9 , and remain high at the secondary level.

Undoubtedly, cultural factors and forces such as early marriage, pregnancy and household responsibilities determine the likelihood that girls will remain in school. Unfortunately, this discrimination only promotes an uneconomic use of valuable human resource for development. In the particular case of Sierra Leone, gender discrimination in education could be equally blamed on religious forces such as Islam and Christianity. Both fundamentalism Christian and Muslim beliefs and expectation of women and girls, which place women in domestic and submission positions in society contribute to keeping women in subordination. In the case of education, girl and women has been considered insofar as it would promote the introduction of the religion of the community.

Additionally, outmoded traditional practices play a large role in keeping the girl child in the background of Sierra Leonean society. Early marriage, betrothal, housekeeping and fosterage contribute in various ways to preventing educational enrolment and when enrolment early exit from school. Parental and community expectations of girls as submissive and the subordinated of their roles and related restrictions in access to family and community resources have implications for the continued subjugation of women and girls. Although marriage if valued highly in the pro-natalist Sierra Leonean society, women as the locus of such productions are lowly valued. Women's re-location in marriage has been a key factor used to deny women and girls' access to family wealth, property and even valued titles and positions.

Yet, the blame does not end with traditional or religious authorities. The state, colonial and post-colonial, has played comparable roles in compromising on women's education, general socio-economic and human rights. When the colonial state became central in educational provision in Sierra Leone, as education moved from informal setting to formal schools, the education of girls and women was not an important issue. There was a concentration on boys' 
education as heirs of the colonial superstructures and supplementary labour to the local colonial machinery. While boys were trained to take on public roles, the few girls who had the opportunity were prepared to domestic service as housewives. The situation was worsened by local resistance. There was much resistance to western education by parents and communities who saw the new schools as a break from their cultural traditions and holds. Worse still was the movement of girls to the formal school. The idea of sending a girl child to school was considered by local communities as abominable. Cultural and religious (Islam) traditions became important propellers of such resistance largely on the basis on morality and economics.

However, the upsurge of social movement in the last two decades or so has served to change the trends and set the tone for enhancing women's status in society. The women, but also men, of Sierra Leone like elsewhere are mobilizing and organizing themselves in many ways to access political, social and economic systems and structures. These movements produced thousands of non-governmental organizations (NGOs) to achieve their aims. The resulting women's groups, associations and organizations have focused on the goal of improving some particular aspects of women's lives. In trying to achieve this goal, the movements have engaged in communication with other groups. They also reach out to community members including politicians, legislators, and the media.

The NGOs communicate their goals to the masses through slogan-bearing T-shirts. Their goals are to create awareness among member groups so that women can be empowered but also demand and/or access their rights to state and community resources and opportunities. Through empowerment programmes that build the capacities of women in income generation, public speaking, advocacy and even awareness creation women are expected to empower themselves in order to exercise their human rights. Areas of emphasis have included reproductive and sexual health, violence against women, resource rights and rights to education and employment in line with the Beijing Platform of Action (1995). Through communication with T-shirts, posters, brochures, radio, newspapers and magazines, women are able to advocate for the reduction of all forms of violence. They advocate on inheritance rights, technical assistance, micro-credit grants and access to technical training programs.

Under and through the UN system women's movement, governments all over the world have agreed that women's empowerment is important and essential for the development of a nation (Manu, 1998; Bunch, 1997). Africa has made many moves in this $21^{\text {st }}$ century to bridge the gender gap. For example, the African Union (AU), which is the successor to the Organization of African Unity (OAU), which was founded in 2002 has achieved gender parity in its executive arm. As part of extending and tackling the specific needs of women, the African Charter on Human Rights includes the Charter on Women's Rights (Kuenyehia, n.d). Also, the AU Commission has stipulated that at least one woman should be included in the Pan-African Parliament (PAP). The decision to create new regional institutions in Africa has enabled groups to push for substantial changes in gender policies. These continental level efforts, together with global movements, are not only paying off at that level but also influencing sub-regional and national levels.

For instance, in the East and Southern African regions, the number of women parliamentarians ranges from 25\% to 50\% (Cutrufelli, 1983).This is because many states have initiated and implemented relevant, and sometimes strategic, legislative reforms in areas such as genderbased violence, land rights, and family laws. Others have included the National Gender Policies 
and Women's Manifestos. Elsewhere, in Africa such as Uganda and Rwanda, governments include women in parliament so as to bring gender parity and to enhance democracy. Stronger gender inclusion in parliaments may bring about an effective government. This could also improve the quality of the public/civil service and policy formulation as well as enhance commitment to gender policy effectiveness.

It is in view of the above development in women's empowerment through capacity building that the motivated this analysis. This paper examines specific programs instituted toward the capacity building of the women of Sierra Leone. The overall objective is to identify action programs for capacity building of women in Sierra Leone. Specifically, it looks at issues on skill training, micro-credit support, girl education and legal reforms. These are analyzed against the background of provisions of the millennium development goals and local initiatives.

\section{THE MILLENNIUM DEVELOPMENT GOALS}

The Millennium Development Goals (MDGs) were contained in a declaration signed in September, 2000 at the UN Millennium Summit. The Summit committed countries, among others, to promote gender equality and the empowerment of women as an effective way to combating poverty, hunger and diseases. It was expected that gender equality and women's empowerment would help build capacities for participating in and stimulating development that is truly sustainable. A year after the adoption of the Millennium declaration, former UN Secretary General, Kofi Annan proposed a 'Road Map' for implementing the millennium development summit goals (Annan, 2001).

The 'Road Map' identified for the MDGs have taken the form of a set of 18 time-bound targets with 48 indicators. The targets and indicators, as should be expected, have been intended to, among others, advance progress in ongoing development agenda. For instance, in the case of goal three on Gender Equality and Women Empowerment, it finds parallels in and has been intended to advance progress on some of the twelve critical areas identified by the Beijing Platform for Action (BPA). The BPA was adopted by all 189 participating UN member countries at the Fourth World Conference on women held in Beijing in 1995. The MDG Goal Three also supports the goal on the Convention for the Elimination of all forms of Discrimination against Women (CEDAW), which was adopted by the UN General Assembly in 1979, has been ratified by170 countries. In Africa, the African Charter of Right and the Protocol of Women's Rights is an important informing framework (Sesay, 2002; Kuenyehia, n.d).

Even though the UN's primary concern is to eliminate poverty totally from the face of the earth, it has also targeted woman as a particularly vulnerable group. In practice this has meant designing relevant responses in the form of establishment of national machineries for women, legal reforms, resources opening and capacity -building for women. This is borne out of the fact that the development of any country depends on women and when women are capacitated it goes a long way to hasten national development. This understanding has made capacitybuilding an important attraction for various development actors and workers.

\section{CAPACIY-BUILDING}

\section{Forms and Practices}


In Sierra Leone, capacity building has taken the form of a delivery system which is usually run by implementing partners, to transfer skills, perspectives, and knowledge to a target population (Josiah, 2001). This could be done through a familiar set of tools such as workshops, class study tours and study tours. It has become a legislative assistance strategy from donors to support democratization efforts.

Capacity building (Steven, 2001) is usually divided into three stages;

- stating the policies to be implemented,

- how they could be implemented in a series of comparative studies, whether it is well or poorly implemented, and

- the lessons that are learnt from the experiences.

On the first, often the goal of donor agencies is the practical instrument that guides behaviour so as to attain the desired results of capacity building; that is the development. United Nations through UNDP has promoted special interest in strengthening legislatures in states, since their duty as key governing institution is to seek the interest of the people, while providing a forum for peaceful mediation of completing views (Annan, 2000).

In Sierra Leone, this is evident in the 50/50 groups, which is sponsored by the British Council in Sierra Leone, who is involved in training potential women political candidates. Through the United Nations Fund for Population Activities (UNFPA), NEWMAP is raising awareness on the benefits of women's education. Pressure groups such as Sisters Unite and Women's Forum are working to ensure that gender equality is integrated into the country's political agenda (Lavallie, 2001).

In the case of the second, identifying action programs for women's capacity building is significant for the following reasons: There is need to tackle the problem of gender imbalance. Fortunately, this is now widely recognized, since the1975 UN Decade For Women, and which implemented in Nairobi in 1985 (sources). For true development to occur in any society, the inequality which exist between men and women, which has constrained their full potentials and active participation in mainstream social, economic and political activities, have to be eliminated. In Sierra Leone, women's representation in politics and the Civil Service was minimal. However, in the government's 2001 National Action Plan for the nation, it was stressed by the Minister of Social Welfare, Gender and Gender Affairs Mrs. Shirley Gbujama, in 2001, that a $30 \%$ representation of women will be made in these areas. It is because of this that Sierra Leone has a 13.2\% female representation now (Government of Sierra Leone, 2001).

Also in Sierra Leone, as elsewhere in Africa, the upkeep of the home tends to rest largely on the women. Women endure the burdens of domestic chores and bear the responsibility of raising the children. Some women, particularly single parents are the breadwinners of their homes and sole sponsors of their children/ward's education. In addition, majority of the women are not gainfully employed due to their lack of education and technical/vocational skills. Such women rely mainly on petty trading and backyard gardening, which cannot withstand the weight of their responsibilities. Therefore, if nothing is done towards their empowerment, the more their hardship grows, the more prone they become to prostitution and unwanted pregnancies, health hazards like STD, HIV/AIDS; with the end result of poverty and social degradation. 
The provision of technical/vocational skills training for women will go a long way to improve their lives. Although the target of the MDG3 on gender equality appears to be associated mainly with eliminating gender disparity in primary and secondary education, the road map includes their additional indicators of gender equality, increase in literacy rates, the share of more women working in non-agricultural jobs and an increase in proportion of seats women hold in national parliaments. It is in light of this that capacity building effort should take it seriously.

The third stage involves lessons learnt from the experience of capacity-building. Capacitybuilding is a long-term process which requires a systematic approach, and both effective demand and supply for public sector performance. In most African countries, the World Bank has broadened its support to include the strengthening of public institutions, with emphasis on financial management, decentralization and governance. However, the Bank's traditional tool, which is technical assistance and training have often proved ineffective to build a sustainable public sector capacity. For example, in Sierra Leone, funds loaned to people to capacitate them were mostly not refunded. This is because the process at the design stage, and capacity building interventions were not properly monitored and evaluated.

Also, majority of projects especially in Africa support training of individual staff which makes them achieve target numbers to be trained. The health and education sector face great challenges, as they are labour intensive and decentralized, thereby relying on thousands of dispersed frontline service providers. Training, however, is only part of the solution building human capacity. What is needed is a comprehensive approach to human resource management.

\section{Capacity-Building Efforts}

\section{Sensitization and Skills Training}

A popular form of capacity-building of women has been the sensitization and training of planners in gender analysis skills through seminars and workshops. This has been aimed at addressing physical, sexual and psychological violence occurring in the family and the society in general. The physical violence includes wife battering, sexual abuse of female children, dowry related to violence and marital rape.

The means of transmitting such information has been through the mass media (radio), drama, songs and dance. It will be necessary for some of this sensitization to be done in some of the local languages, since illiteracy rate is still high in the country, especially at grass root level. One thing worthy of note, especially in the education of the girl child is that it is not enough to make schools available to girls. It is important for conducive environments to be created that support girls to enrol, stay and perform and graduate.

In Sierra Leone, there is still the problem of attracting girls to schools and of persuading parents to send their girl children. This is because girls are kept at home to look after their younger brothers and sisters, or they cannot go to schools that have male teachers. Parents are afraid that the male teachers may either seduce these girls or impregnate them. This has really been happening although the country's educational policy is against it. Generally, the teacher's position of authority, influence on their pupils, students desire to be liked, and poverty makes them to take advantages over the pupils. Even in this day and age, some girls are not allowed to 
go to school simply because they are destined to be wives and mothers, and therefore do not need education (Sesay, 2002).

After the 11 years rebel war in Sierra Leone (1991-2002), many non-organization and donor countries have poured money in the country. These non-governmental organizations are only staying in the country for a period of time. The citizens have to be sensitized that building a nation depends not on begging from other states, but from their own efforts. This cannot be achieved unless women are part of these building programs. Male chauvinistic and state parsimony or patrimony undermine rather than promote national, sustainable and holistic development (Mansaray, 2008; Tsikata, 2000; Manu, 1998).

\section{Provision of Micro-credit Facilities}

Another way that the capacity-building of the women of Sierra Leone has been promoted has been through the provision of micro-credit facilities for economic empowerment. Micro-credits are loans of small amount of capitals given to poor borrowers for self employment projects, so as to enable them earn their own incomes, increase their productivity, and allow them to become self-reliant. Micro-credit facilities were introduced in Sierra Leone from the 1990s. Micro-credits allow women to borrow money from NGOs and Banks, especially Cooperative Banks. For instance, market women engaged in gardening, whose proceeds are used largely for home consumption. As most women in Sierra Leone are not fortunate to go through formal education, $50 \%$ are engaged in gardening and small scale business (Government of Sierra Leone, 2004).

Women generally are deprived from gaining access to financial resources generated jointly by their partners. The micro-credit facilities thus serve as cushioning for their economic empowerment. A just society should provide its citizens with enough economic means to satisfy their basic needs.

\section{Promoting the education of the girl child}

Another avenue is the promotion of girls' education. Bold steps should be taken by the government of Sierra Leone and non-governmental organizations (NGO) to promote the education of the girl child. By so doing girls can become self-reliant, or gain access to employment opportunities. Educating a girl child to be able to grow into useful adulthood and take active part in planning and executing development programs will be an important step forward. Through education, such girls can acquire job skills that will empower them economically, intellectually, and hence elevate their status in society. Education will help alleviate poverty and the suffering of girls and the nation in general. It will bring about a change in the lifestyle of the girl child by maintaining her self-respect in the society.

Due of the past rebel war, many rural areas have very few schools in villages. This situation makes it difficult for many children to access schools. However, communities have begun to address the issue by establishing feeder schools of up to class 4 in their villages. Girls lack behind boys in educational output especially in the East and North than South and West of the country (Lahai, 2005). To encourage girls from the areas, the Ministry of Education, Science and Technology (MEST) adopted the "Girl Child Support Education "policy in 2003. With this policy, MEST states that every girl child who passes the National Primary School Examination (NPSE) 
in both the East and North of the country will receive free school fees, core text books, pencils, pens, geometry sets, two sets of uniforms and a pair of games tunic, with a total sum of Le 300,000 (\$120) per child.

The Forum for African Women Educationists (FAWE), which has been established in the country since 1992, and whose goal is to close the gender gap, with particular focus on girl child education, has established technical vocational schools for girls in all fourteen administrative districts in the country. This will help girls who get pregnant or are lactating mothers to acquire skills so as to get their livelihoods.

As early and sometimes forced marriages are practiced in Sierra Leone, UNDP through Parliament, Law Reform Commission and human rights organizations have conducted a nationwide sensitization on aspects of the Convention on the Elimination of All Forms of Discrimination against Women (CEDAW). This has helped Parliament to draft the Customary Marriage Act which forbids girls to marry below the age of 18, with or without their consent. This law will prevent parents from removing their girl child from schools till they finish high school education.

\section{A conducive atmosphere for participation in political activities}

Giving women opportunities to participate in political activities will help them manifest their hidden talents, roles and responsibilities in society, which is vital to socio-economic development. Sierra Leone has a long tradition and history of women's participation in politics. Women have been queens in the East and South of the country even before the colonial era. Examples of women such as Paramount Chief, Madam Humornya of the Kenema District in the East and Paramount Chief, Madam Ella Kobolo-Gulama of the Moyamba District in the South were both rulers in their districts and Parliamentarians in the national government.

For the past 13 years, women have been part of the national government, and most of them have been part of the national parliament. However, they have been in small number, and most times they are still marginalized because they are women $(13.2 \%$, as indicated by the July, 2009 Inter-Parliamentary Union Report). They are not even allowed to take part in active discussions in parliament. Sometimes when the woman becomes outspoken and try to criticize issues, male parliamentarians will say that she is trying to be a man. All these attitudes must be changed for a better society to prevail in Sierra Leone.

\section{Support for Gender Equality Programs}

In the 2001 National Plan of Action by the government, it has been indicated that there is a lack of education/sensitization on democratic values that can promote women and men's equal participation for the development of the nation. Since 1999, Ministry of Social Welfare, Gender and Children's Affairs had developed National Policy on Gender Mainstreaming which provides a framework for the systematic integration of gender as a fundamental component for all development policy and programme in the government, private sector and the civil society. The Ministry also developed the National Policy on the Advancement of Women in Sierra Leone, wherein the disadvantaged position of women was addressed. Both documents were approved 
by Cabinet in August, 2000; which seeks to meet the development objectives from gender perspectives (Gbujama, 2001).

The Sierra Leonean Ministry of Social Welfare, Gender and Children's Affairs does not always have funds to undertake mainstreaming support programs, especially during emergencies like draught and earthquake, as is the case in other African countries. Government of Sierra Leone should therefore encourage NGOs and donor countries to pay attention to this ministry.

Where there is resource, emphasis must be laid on skill training such as Gara tie dying, soap making, tailoring, weaving, catering, hair dressing and other vocational occupations. At the end of these trainings, women should be provided with tools, and an initial help with kits to set them on a sound footing. Priority should be especially given to teenage mothers, illiterate housewives and single mothers.

Another important issue that must be addressed in gender support program in Sierra Leone is Adult Education. By giving women, particularly market women the basic literacy and numerical skills will help them to communicate with their business partners. This will help them know how to calculate during business transactions.

Family Support Unit has been established to counter domestic violence in Sierra Leone. This unit must be provided with adequate financial and logistic support so that they could champion the course of women.

\section{CONCLUSION}

Discrimination against women is not only a global issue, but an age old phenomenon. Women have always been treated as sub-humans all over the world. Sierra Leone, like any other part of the world has had its own share of unequal treatment in terms of education, employment facilities and political participation in other social activities.

However, over the years, attempts have been made by the UN to improve the status of women in the globe. This has resulted in the global cry of gender equality, which has made it possible for various gender biased organizations to try to promote and elevate the status of women. Capacity building for women is one of the ways to free them from the bondage of male domination. Giving women an equal treatment with regards to educational, economic, social and political opportunities will do this. This will increase their earning capacity and make them feel capable to cope with their daily needs.

Sierra Leone, though it has not achieved a gender balanced society, yet the governments with the help of NGOs and other international agencies are putting law reform action plans into place to achieve this goal. With this view of gender equality, there has been an increase in women's political involvement. Female registration has also increased in schools, through sensitizations by NGO's and the government. For now, the society is more aware that development could only take place through gender equality. Most women who were just ordinary housewives are now engaged in income generating activities. As capacity building is a long term process, Sierra Leone might likely achieve the objectives of the millennium development goal.

\section{SUGGESTIONS}


The following suggestions have been made to achieve the goals of capacity building activities in Sierra Leone:

- To sensitize and train planners in gender analysis skills through seminars and workshops.

- To provide micro-credit facilities for the empowerment of women.

- To provide for the education of the girl child.

- To provide gender support programs that will equip women with vocational and technical skills.

- To provide a conducive atmosphere for women's participation in political activities.

- To provide women with law reform action plans.

\section{REFERENCES}

Annan, Kofi (2005). The Millennium Development Goal Report: United Nations. (online). Available: www.un.org/summit2005/MDGBOOK.pdf 2005

Annan, Kofi (2001, September). Road Map Towards the Implementation of the United Nations Millennium Declaration: Report of the Secretary General to the General Assembly. A/56/326.

Annan, Kofi (2000, September). Resolution Adopted by the General Assembly: United Nations Millennium Declaration. A/55/L.2.

Bunch, Charlotte (1997). “Women's Rights are Human Rights." Report of the $1^{\text {st }}$ African Women's Leadership Institute. Kampala, Uganda: Akina Mama wa Africa.

Cutrufelli, M.R. (1983). Women Of Africa: Roots of Oppression. London, UK: Zed Press, pp.41-46.

DHWN (1986). Development crisis and alternative visions: Third World women's perspectives: Canadian Women Studies. 7 (1\&2). 31-33.

Dutton, D.G. (1995). The Domestic Assault of Women: Psychological and Criminal Justice Perspectives. Vancouver, Canada: UBC Press, pp.1-25

Durr, M.(2002). Special issues on African-American women: Gender relations at work, and political economy in the Twenty First Century. Gender and Society, 16 (4), PP. 6-14.

Gbujama, Shirley (2001). Women and Men in Partnership for Post War Reconstruction: Report of the Sierra Leone National Consultation.1 (1) p. xiii.

Josiah, Iyesha. (2001). Women and Men in Partnership for Post War Reconstruction: Capacitybuilding, Coordination and Networking, 1 (1) pp.175-80.

Kenny, S \& S. (2001). Nonprofit Life Cycles: Staged-Based Wisdom For Nonprofit Capacity. Long Lake, MN, USA: Stagewise Enterprises, Inc. pp.15-20.

Kuenyehia, Akua (n.d.). CEDAW Daily Implementation in Ghana. Accra, Ghana: WILDF/EU.

Lahai, Bernadette (2005). United Nations Commission on the status of Women, Fifth Session. (online). Available: www.un.org/womenwatch/daw/csw50/statement/csw50-Panel 1. 27th February- 10th March. 
Lavallie, E. (2001). Women and Men in Partnership for Post War Reconstruction: Gender Equality in Political and Public Decision-making, 1 (1) pp. 39-42.

Mansaray, Sidikie Abu (2007). "Gendered Politics, Political Culture and the Crisis of Democratization in the ECOWAS Sub-region of Africa." Studies in Gender and Development in Africa, Vol. 1: 70-90.

Manu, Takyiwaa (1998). “Women in Africa's Development: Overcoming Obstacles, Pushing for Progress. "Briefing Paper: African Recovery 11 (April). New York, United Nations Dept. of Public Information.

Ogundipe-Leslie, Molara (1994). Recreating Ourselves: African Women and Critical Transformation. Trenton, NJ: Africa World.

Pan-African Parliament (Abuja Treaty of 1991)/African Union in Addis Ababa, Ethiopia (2007, January 22-30), Inter-parliamentary Union Report 2007 (National Parliament of Sierra Leone, 31 August, 2009).

Rogers, J. D (2001), Women and Men in Partnership for Post War Conflict Reconstruction: The Government's Commitment to Poverty Alleviation, 1(1) pp.113-20

Sesay, T.B.M. (2002). Factors Affecting the Education of the Girl child in Selected Senior Secondary Schools in Kenema Township. BA Dissertations, Njala University College, Unpublished).

Sierra Leone Government (2004). Micro Finance Programme Development. Freetown, Sierra Leone: $7^{\text {th }}$ Meeting of the Development Committee.

Sierra Leone Government (2001). Report of the Sierra Leone National Consultation. Freetown Sierra Leone: Ministry of Social Welfare, Gender and Children's Affairs.

Tsikata, Dzodzi and Kerr, Joanna (2000). Demanding Dignity: Women Confronting Economics Reforms in Africa. Ottawa, ON: North-South/Third World Network.

Tsikata, D. (2000). Lip-Service and Peanuts: The State Machinery for Women in Africa. National Machinery Series). Accra, Ghana: Third World Network. 